\title{
How Does China's New Consumption Era Reshape Residents' Shopping Behaviors from the Perspective of Community in Hohhot, China
}

\author{
Fangqu Niu ${ }^{1}$ (D) and Fang Wang ${ }^{2, *(\mathbb{D})}$ \\ 1 Institute of Geographic Sciences and Natural Resources Research, Chinese Academy of Sciences, \\ Beijing 100101, China; niufq@lreis.ac.cn \\ 2 School of Public Administration, Inner Mongolia University, Hohhot 010070, China \\ * Correspondence: wangf741@163.com
}

Citation: Niu, F.; Wang, F. How Does China's New Consumption Era Reshape Residents' Shopping Behaviors from the Perspective of Community in Hohhot, China. Sustainability 2021, 13, 7599. https:// doi.org/10.3390/su13147599

Academic Editor: Jun Yang

Received: 16 June 2021

Accepted: 2 July 2021

Published: 7 July 2021

Publisher's Note: MDPI stays neutral with regard to jurisdictional claims in published maps and institutional affiliations.

Copyright: (c) 2021 by the authors. Licensee MDPI, Basel, Switzerland. This article is an open access article distributed under the terms and conditions of the Creative Commons Attribution (CC BY) license (https:// creativecommons.org/licenses/by/ $4.0 /)$.

\begin{abstract}
In the new consumption era, the popularization and application of information technology has continuously enriched residents' consumption channels, gradually reshaping their consumption concepts and shopping behaviors. In this paper, Hohhot is taken as a case study, using open-source big data and field survey data to theorize the characteristics and mechanism of residents' shopping behaviors in different segments of consumers based on geography. First, communities were divided into five types according to their location and properties: main communities in urban areas (MCs), historical communities in urban areas (HCs), high-grade communities in the outskirts of the city (HGCs), mid-grade communities in urban peripheries (MGCs), and urban villages (UVs). On this basis, a structural equation model is used to explore the characteristics of residents' shopping behaviors and their influencing mechanisms in the new consumption era. The results showed that: (1) The online shopping penetration rate of residents in UVs and HCs is lowest, and that of residents in HGC is highest. (2) The types of products purchased in online and offline shopping by different types of community show certain differences. (3) From the perspective of influencing mechanisms, residents' characteristics directly affect their shopping behaviors and, indirectly (through the choice of community where they live and their consumption attitudes), their differences in shopping behaviors. Different properties of communities cannot directly affect residents' shopping behaviors, but they can affect them indirectly by influencing consumption attitudes and then affect such behaviors. Typical consumption attitudes of the new era, such as shopping for luxuries and emerging consumption, have the most significant and direct influence on shopping behaviors, as well as an intermediate and variable influence.
\end{abstract}

Keywords: new consumption era; type of community; shopping behavior; SEM; China

\section{Introduction}

Information and communication technologies (ICT) have experienced a persistent increase in usage over the past decades, the latest Grand View Research report [1] estimated a worldwide online shopping market of about 190 billion USD, predicting a composed annual growth rate of $24.8 \%$ from 2020 to 2027 . In China, the consumption patterns and shopping behaviors of residents have undergone great change in recent years, driven in particular by the development of the worldwide web, artificial intelligence, and the incremental improvements in access to technology. In 2015, the State Council officially put forward the concept of "new consumption", and stated that China had entered an important stage of sustained growth in consumer demand, accelerated upgrading of the consumption structure, and marked enhancement of the role of consumption in driving the economy. Since then, China has officially entered the "new consumption" era.

The new consumer era is an evolution of the Internet era. In the previous Internet era, online and offline retail provided consumers with more choices. Therefore, consumers 
had more transparent prices than traditional shopping, and they were willing to pay for cost-effective products. In the new consumption era, with the advent of big data, artificial intelligence and smart manufacturing, retailers can collect customized information through applications and sensors of the phones, tablets, and computers. Retailers can provide more personalized products in a targeted manner. At the same time, consumers' demands for products are getting more and more complex. The consumers pay increased attention to quality of life and self-development, their demands for products range from pure product functional satisfaction to individualized and spiritual satisfaction. The additional attributes brought by place, content, and service to products are also becoming more and more important, and products are becoming more personalized and interactive in the new era. In addition, unlike the Internet era, which separates entertainment, social interaction, and shopping; these scenes in the new consumption era continue to integrate, allowing shopping while entertainment and social interaction [2,3].

As such, in this new consumption era, emerging consumption habits continue to spring up, and mass consumption behaviors and lifestyles have undergone profound changes. There is the coexistence of emerging shopping patterns and traditional shopping patterns, and the symbiosis between offline shopping and online shopping. As such, in the new consumption era, what changes have taken place in the consumption attitudes and behaviors of Chinese residents? How do the new consumption attitudes reshape shopping behaviors? Are there differences in shopping behaviors in different communities? Especially in relatively backward areas in China. These can provide references for urban commercial development and commercial space optimization. Empirical studies to date have not addressed the issue so far.

Therefore, this study fills the gap. It takes Hohhot as the research object, and, using residential data and residents' shopping behavior questionnaires, classifies communities, systematically analyzing the characteristics of residents' shopping behaviors in the new consumption era. Next, it adopts a structural equations model (SEM) to illustrate the relationships among residents' characteristics, community attributes, consumption attitudes and shopping behaviors in the new consumption era. This provides a scientific reference for the development of urban commerce.

We organized the paper as follows: The second section reviews the literature on the emerging shopping behaviors. Section 3 presents the study area, the data, and the classification of communities in the study area. Section 4 discusses characteristics of shopping behaviors. Section 5 analyzes the mechanisms of shopping behaviors. The final section summarizes the key findings.

\section{Literature Review}

Past research on shopping behaviors has been the field of joint research in economics, psychology, geography, and other disciplines. Since Berry (1958) put forward the theory of the "tertiary sector of economic activity", geographers have begun to pay attention to consumption preferences and consumption ability. This research can be divided into two classes: (1) The characteristics of residents' behaviors and their influencing factors; i.e., the characteristics of residents' shopping behaviors in different areas $[4,5]$ and the characteristics of shopping behaviors of different people at different times [6-9]; (2) The simulation study of shopping behavior models, such as aggregate models, gravitation models, the Markov chain model, the discrete choice model of simulating individual behaviors, and the shopping behavior model of the multi-agent system [10,11].

Since the 1990s, urban commerce has entered a transition period, and research on new commercial development and the emerging shopping behaviors is increasing [12-14]. For example, Ingham et al. (2015) have discussed residents' acceptance of the degree of different shopping patterns and its influencing factors [15]; Zhen et al. (2016) discussed the spatial characteristics of urban residents' online shopping behaviors and their influencing factors [16]. Scholars have different opinions on the relationship between online shopping and offline shopping, which can be divided into four kinds: substitution, independence, 
supplement, and promotion [17-19]. For example, Zhang and Zhen (2017) found that online shopping has a greater impact on the traditional offline shopping of search-based goods, mainly based on the mode of substitution and independence; the impact of experiencebased goods has less of an impact on offline shopping; the shopping behavior of residents is still dominated by the independent mode [20]. Shi (2019) found that the number of physical stores for clothes and shoes, electronics, food and drink, and cosmetics may all decrease in the long run in China [21].

The research on the influencing factors of shopping behaviors can basically be divided into two categories: First, the residents' socio-economic and individual attributes; Second, the environmental characteristics such as traffic, services, etc., that affects a residents' shopping behavior [22-24]. In addition, in recent years, some scholars have found that the shopping behaviors are also affected by the activity space before and after shopping, and these two spaces are likely to be residential spaces. Therefore, in recent years, scholars have also begun to pay attention to the relationship between commercial space and residential space [25-27]. For example, Wang Fang et al. (2019) conducted a coupling analysis of urban commercial districts and housing blocks in Beijing, yielding insights into the optimization of the urban commercial structure [28].

Generally speaking, research on shopping behaviors started early, and the impact of new consumption on traditional shopping behaviors has become a hot topic of research in recent years. However, current research mainly focuses on the overall behavioral characteristics of all urban residents using prior theories, lacking analysis on differences between residents' shopping behaviors in different residential spaces.

In particular, how the arrival of new consumption will affect residents' consumption attitudes and shopping behaviors, and the mechanisms of them, has not yet been examined. In addition, China's western cities are weak in urban infrastructure and have low social development, which distinguishes them from developed regions. Current research concentrates on the eastern developed cities, such as Beijing, Guangzhou, Nanjing, and Shanghai [29,30]; therefore, it is of great theoretical and practical value to carry out a systematic study on the shopping behaviors of urban residents in the cities of western China. Hohhot is the capital of Inner Mongolia in China, a typical city in the western regions.

\section{Study Area and Methodology}

\subsection{Study Area}

Hohhot is the center of politics, economics, and culture in Inner Mongolia and is located in the middle of Inner Mongolia, with four urban districts under its jurisdiction: Xincheng District, Saihan District, Huimin District, and Yuquan District, as well as five counties. At present, the urban population and socioeconomic activities in Hohhot are mainly concentrated in and around the second ring road, so this study area uses the area within the second ring road and $2 \mathrm{~km}$ outside of it, where the east second ring road extends to the Horqin Expressway (Figure 1). 


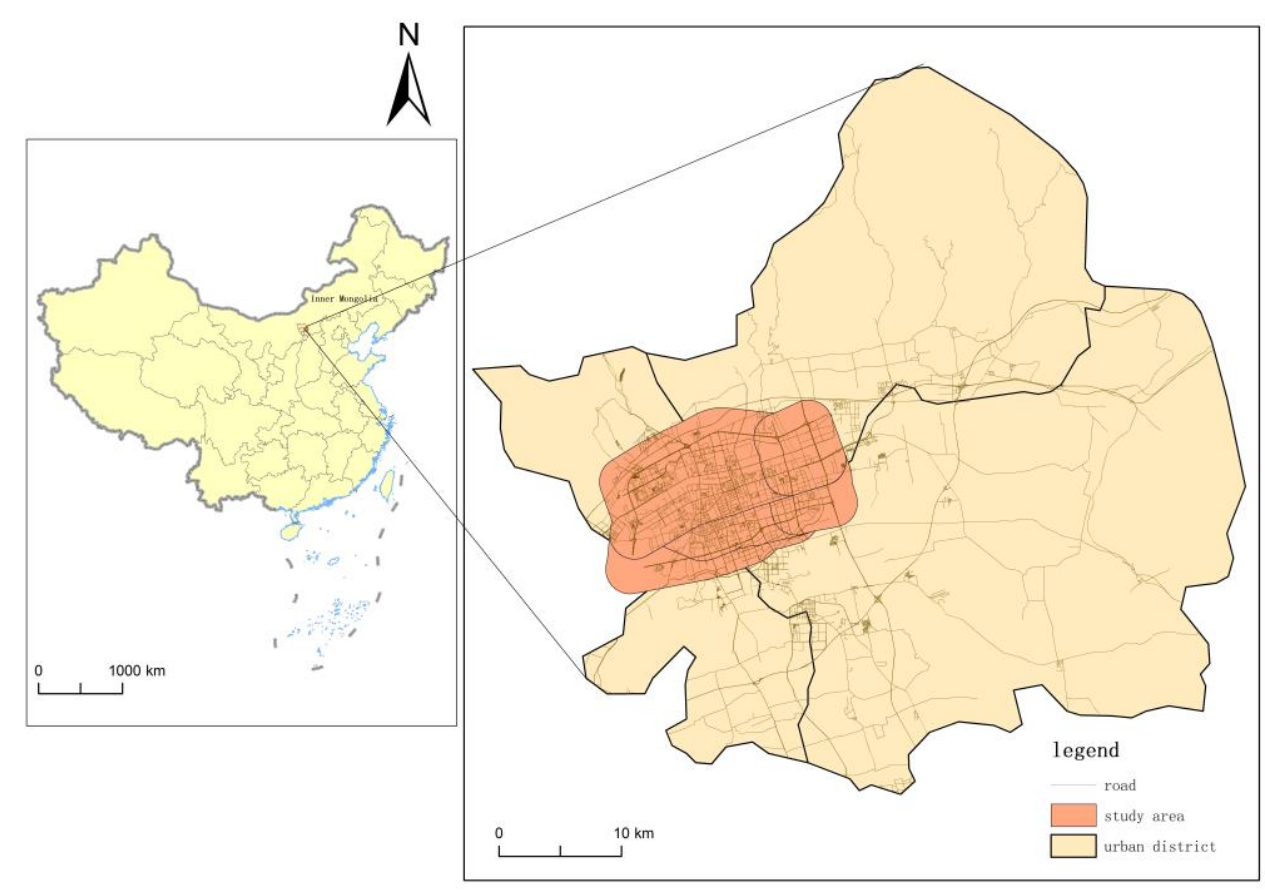

Figure 1. Study area.

\subsection{Methodology}

\subsubsection{Spatial Clustering Grouping}

The clustering method of GIS grouping analysis comprehensively considers the attribute factors and spatial characteristics of the research object. Compared with other clustering methods, its biggest advantage is that the clustering process considers the geographic spatial location of the elements. Grouping effectiveness is mainly measured by the pseudo F statistic, which is used to reflect the ratio of component similarity to difference within a group. The calculation is as follows:

$$
\begin{gathered}
F=\left(\frac{R^{2}}{n_{c}-1}\right) /\left(\frac{1-R^{2}}{n-n_{c}}\right) \\
R^{2}=\frac{S S T-S S E}{S S T} \\
S S T=\sum_{i=1}^{n_{c}} \sum_{j=1}^{n_{i}} \sum_{k=1}^{n_{v}}\left(V_{i j}^{k}-V^{k}\right)^{2} \\
S S E=\sum_{i=1}^{n_{c}} \sum_{j=1}^{n_{i}} \sum_{k=1}^{n_{v}}\left(V_{i j}^{k}-V_{i}^{k}\right)^{2}
\end{gathered}
$$

SST is the difference between groups, SSE is the difference within a group, $n$ is the number of communities, $n_{i}$ is the number of communities in the $i$-th group, $n_{c}$ is the number of groups, $n_{v}$ is the number of group variables, $V_{i j}^{k}$ is the value of the $k$-th variable of the $j$-th community in the $i$-th group, $V_{i}^{k}$ is all the value of the $k$-th variable of the communities, and $V_{i}^{k}$ is the value of the $k$-th variable of all the communities in the $i$-th group.

\subsubsection{Structural Equation Model}

Structural equation modelling (SEM), an approach that has recently gained popularity in shopping studies [31,32], was used to test the hypothesis. SEM is a quantitative research model based on statistical analysis techniques to deal with multi-factor causality. The SEM uses the covariance matrix of variables to explore the interaction between variables and is also known as covariance structure analysis. The SEM not only considers the internal 
structure of factors, but also pays attention to the measurement of the causal relationship between factors. The SEM can integrate factor analysis and path analysis well. Using comprehensive factor analysis, path analysis, regression analysis, and analysis of variance, SEM can solve the problems of variable relationships with multiple causes and multiple results that cannot be solved using the traditional statistical methods found in economics, management or variables that are not directly observable (i.e., latent variables), and can perform latent variable estimation and parameter estimation of the complex independent variable/dependent variable prediction model. Therefore, SEM is suitable for exploring the causal relations among a number of factors that are supposed to influence each other. Therefore, this paper uses the SEM to identify the factors affecting the shopping behavior of residents in Hohhot. The general expression for the SEM is:

$$
\begin{gathered}
\eta=\beta \eta+\Gamma \xi+\xi \\
y=\Lambda_{y} \eta+\varepsilon \\
x=\Lambda_{x} \xi+\delta
\end{gathered}
$$

Equation (5) is the structural model part of the SEM, which describes the causal relationship between the latent exogenous variable and the latent endogenous variable assumed in the research model; $\beta$ is the relationship between the endogenous variables represented by the random connection matrix; $\Gamma$ is the exogenous change in the influence of a quantity on the endogenous variable represented by the direct random effect matrix; And $\xi$ represents the vector formed by the residual term. Equations (6) and (7) are the measurement models, which, respectively, describe the relationship between the latent endogenous variable $\eta$ and the explicit endogenous variable $y$, and the latent exogenous variable $\xi$ and the explicit exogenous variable $x$. The relationship between $\Lambda y$ and $\Lambda x$ represents the regression coefficients or the factor loading matrix of the recessive variables $\eta$ and $\xi, \varepsilon$, and $\delta$ represent the measurement errors of the explicit variables $y$ and $x$. More details about the structural equations model can be found in Bollen (1989) [33] and Golob (2003) [34].

\subsection{Data and Hypotheses}

\subsubsection{The Spatial Classification of the Communities}

In China, urban land use patterns are affected by marketization factors on the one hand, and regulated by government institutional factors on the other, resulting in the residents' housing selection process being very different from those in the West. Following Alonso's urban land use model, residents choose their living space based on their own economic and other attributes [35]. Moreover, the literature shows that [36,37], in Chinese cities, the type of communities represents to a certain extent the social attributes of resident. On the one hand, residents' shopping behaviors are affected by their own socio-economic attributes, and on the other hand, it is closely related to the type of communities. Therefore, in this paper, we classified all the communities in the study area.

The data on communities come from the famous real estate website Anjuke (https: / / huhehaote.anjuke.com/) (accessed on 1 September 2019). The community data included the address of the community, housing prices, greening rates, and other attributes.

Then this study conducted a spatial clustering analysis of all the communities in the study area of Hohhot. In order to fully consider their attributes, the space neighborhood rule was used to cluster the communities. Using pseudo $\mathrm{F}$ analysis, and taking into account the actual situation, the communities in the study area were divided into four categories. According to the characteristics of price, location, property cost, and building age, the four types of community were: urban areas (MCs), historical communities in urban areas (HCs), high-grade communities in the outskirts of the city (HGCs), and mid-grade communities in urban peripheries (MGCs). In addition, the study took into account the city of urban village (UV) as a special community (Table 1 and Figure 2a). 
Table 1. Characteristics of community types in Hohhot.

\begin{tabular}{|c|c|c|c|c|c|c|}
\hline Types & $\begin{array}{l}\text { Average Price } \\
\text { in } 2019.11 \\
\left(\text { yuan } / \mathbf{m}^{2} \text { ) }\right.\end{array}$ & $\begin{array}{c}\text { Average } \\
\text { Distance from } \\
\text { City Center } \\
(\mathbf{k m})\end{array}$ & $\begin{array}{c}\text { Average } \\
\text { Property Cost } \\
\text { (yuan } / \mathrm{m}^{2} \text { per } \\
\text { Month) }\end{array}$ & $\begin{array}{l}\text { Average Age of } \\
\text { Construction } \\
\text { (Year) }\end{array}$ & Quantity & $\begin{array}{l}\text { Number of } \\
\text { Cases in This } \\
\text { Paper }\end{array}$ \\
\hline MC & 12,167 & 2.46 & 0.49 & 2007 & 930 & 8 \\
\hline $\mathrm{HC}$ & 12,202 & 3.29 & 0.63 & 1999 & 348 & 3 \\
\hline HGC & 13,474 & 5.9 & 2.17 & 2011 & 176 & 3 \\
\hline MGC & 8585 & 5.7 & 0.69 & 2009 & 501 & 2 \\
\hline
\end{tabular}

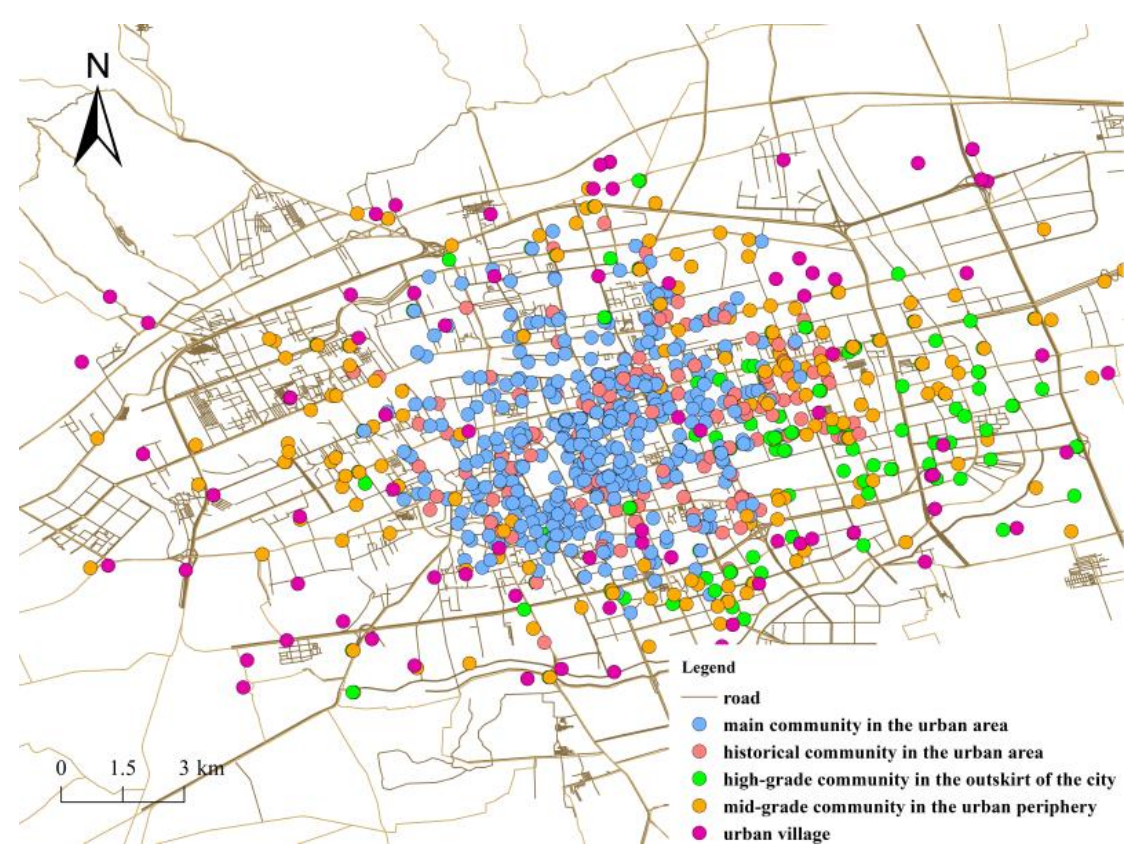

(a)

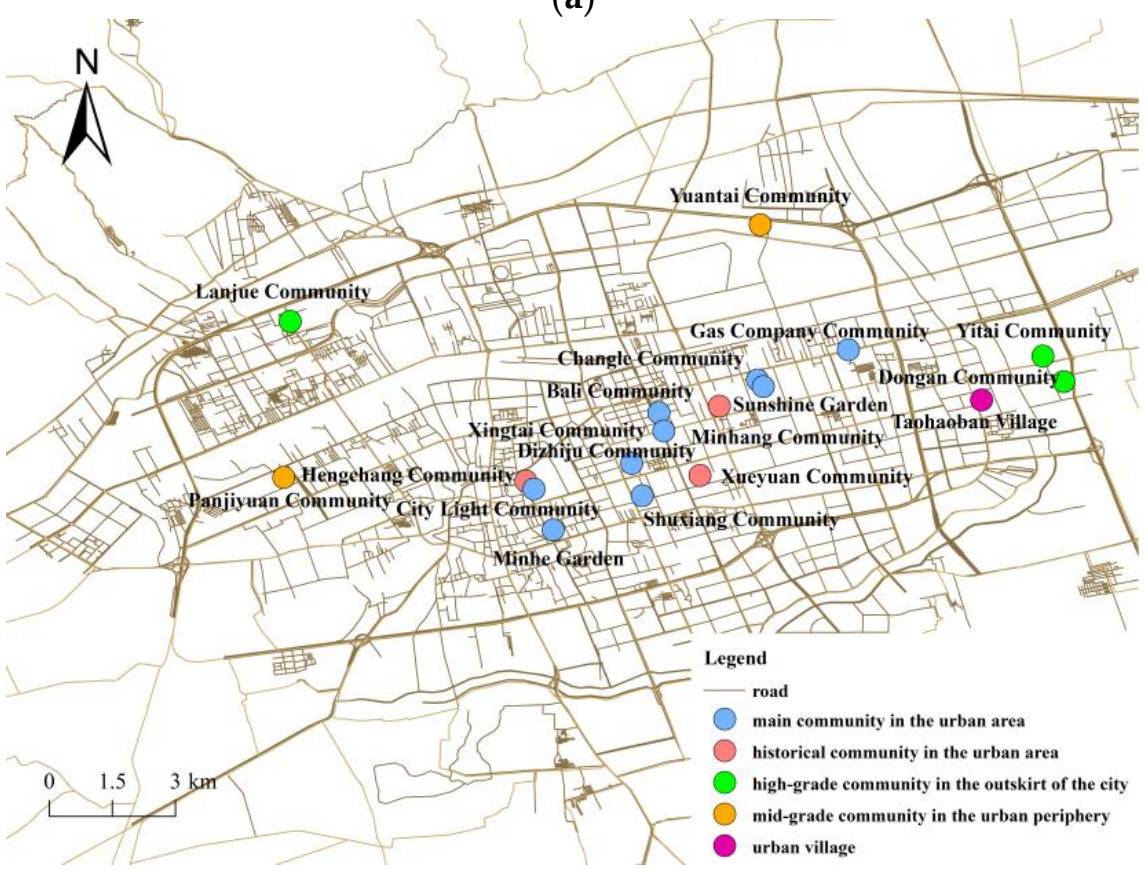

(b)

Figure 2. Type and distribution of urban community in Hohhot: (a) Urban communities in Hohhot; (b) Typical cases of different kinds of communities. 
MCs are the largest number of communities in the city, are mainly distributed in the core area of the city; the average house price is $12,167 \mathrm{CNY} / \mathrm{m}^{2}$, the construction period is relatively long, usually ten years, the transportation is convenient, and the surrounding infrastructure facilities are relatively mature. HC are mostly distributed in the city's inner ring, where the location is better, the average house price is $12,202 \mathrm{CNY} / \mathrm{m}^{2}$, but the buildings are often old, the plot rates of these communities are low, and the green environment poor; residents mostly consist of elderly people and tenants. HGC are most of the villas and bungalows in the city; an average price of these communities is $13,474 \mathrm{CNY} / \mathrm{m}^{2}$, which have a better environment and services, and a higher quality of the buildings. In terms of spatial distribution, HGCs are mostly distributed on the outskirts of the city, and public transport facilities are not convenient. MGCs are mostly distributed in the surrounding areas of the city near the second ring road. The average house price in the MGC is $8585 \mathrm{CNY} / \mathrm{m}^{2}$, which is the cheapest of all four types of community. The surrounding environment of MGC is relatively ordinary, possessing facilities urgently requiring improvement and non-convenient public transportation. There were 82 villages in the study area.

\subsubsection{Samples and Data Collection}

As discussed above, the same type of communities have high homogeneity in many elements such as surrounding infrastructure and residents' characteristics, the shopping behaviors are closely related to the type of communities. Considering the workload of questionnaire surveys and field investigations, 1-8 typical cases from each type of community were selected. Since the number of MCs were the largest and the most widely distributed, we selected 8 cases, and 2-3 cases for other types of communities, all of which were located in different districts and roads. And we choose Taohaoban village from the UVs (Figure 2b).

From October to November 2019, on-site questionnaire surveys of residents' shopping behaviors in the 16 typical cases of communities were carried out. The number of questionnaires depended on the size of the community. The larger the size of the community, the greater the number of questionnaires. Then, the questionnaires were distributed by investigators to community residents through random sampling. Respondents were recruited through door knocking or in open spaces of the chosen communities by faceto-face interviews. A pen or wipes (worth $5 \mathrm{CNY}$ ) was offered as an incentive for survey participation. We invited 612 residents, 508 answered the survey (with a response rate of $83 \%$ ). After removing 3 questionnaires with many missing responses, we used a sample of 505 residents for this study.

The content of the questionnaire included residents' characteristics, their shopping behaviors, and their new consumption attitudes (Table 2). Firstly, the questionnaire included several residents' characteristics: gender, age, occupation, and Engel's coefficient. Secondly, the questionnaire asked respondents to report their shopping behaviors. For example, how often they conduct online shopping on a four-point scale ranging from "Never" to "all". In the sample, more than $40 \%$ of the respondents always conducted online shopping. Thirdly, residents' shopping behaviors usually depends on their perceptions of the consumption [38], therefore, in the survey, respondents were asked to indicate their consumption attitude about fashion, luxury, impulse, excessive and emerging consumption, respectively. 
Table 2. The variables of influencing factors structural equation modeling of residents' shopping behaviors in Hohhot.

\begin{tabular}{|c|c|c|c|c|c|c|c|c|c|}
\hline $\begin{array}{c}\text { Latent } \\
\text { Variable }\end{array}$ & $\begin{array}{c}\text { Observed } \\
\text { Variable }\end{array}$ & $\begin{array}{c}\text { Variable } \\
\text { Type }\end{array}$ & Number & Percentage & $\begin{array}{c}\text { Latent } \\
\text { Variable }\end{array}$ & $\begin{array}{c}\text { Observed } \\
\text { Variable }\end{array}$ & $\begin{array}{c}\text { Variable } \\
\text { Type }\end{array}$ & Number & Percentage \\
\hline \multirow{15}{*}{$\begin{array}{c}\text { Residents' } \\
\text { characteristics }\end{array}$} & Gender & $\begin{array}{l}\text { Categorical } \\
\text { variable }\end{array}$ & & & \multirow{5}{*}{$\begin{array}{l}\text { Property of } \\
\text { community }\end{array}$} & $\mathrm{MC}$ & $\begin{array}{c}\text { Virtual } \\
\text { variable }\end{array}$ & 228 & $45 \%$ \\
\hline & male & 0 & 248 & $49.1 \%$ & & $\mathrm{HC}$ & $\begin{array}{c}\text { Virtual } \\
\text { variable }\end{array}$ & 95 & $18.8 \%$ \\
\hline & female & 1 & 257 & $50.8 \%$ & & HGC & $\begin{array}{c}\text { Virtual } \\
\text { variable }\end{array}$ & 76 & $15 \%$ \\
\hline & Age & $\begin{array}{c}\text { Rank } \\
\text { variable }\end{array}$ & & & & MGC & $\begin{array}{c}\text { Virtual } \\
\text { variable }\end{array}$ & 74 & $14.7 \%$ \\
\hline & $<18$ & 1 & 62 & $12.3 \%$ & & UV & $\begin{array}{c}\text { Virtual } \\
\text { variable }\end{array}$ & 32 & $6.3 \%$ \\
\hline & $19-34$ & 2 & 151 & $29.9 \%$ & \multirow{29}{*}{$\begin{array}{c}\text { New } \\
\text { Consumption } \\
\text { attitude }\end{array}$} & Fashion & Rank & & \\
\hline & $35-50$ & 3 & 125 & $24.8 \%$ & & consumption & variable & & \\
\hline & $\begin{array}{c}51-65 \\
>65\end{array}$ & $\begin{array}{l}4 \\
5\end{array}$ & $\begin{array}{l}88 \\
79\end{array}$ & $\begin{array}{l}17.4 \% \\
15.6 \%\end{array}$ & & $\begin{array}{l}\text { Never } \\
\text { Rarely }\end{array}$ & $\begin{array}{l}1 \\
2\end{array}$ & $\begin{array}{c}63 \\
220\end{array}$ & $\begin{array}{l}12.5 \% \\
43.6 \%\end{array}$ \\
\hline & Occupation & $\begin{array}{c}\text { Categorical } \\
\text { variable }\end{array}$ & & & & Occasionally & 3 & 139 & $27.5 \%$ \\
\hline & $\begin{array}{l}\text { Irregular } \\
\text { occupation }\end{array}$ & 0 & 299 & $59.2 \%$ & & Constantly & 4 & 83 & $16.4 \%$ \\
\hline & $\begin{array}{l}\text { Fixed } \\
\text { occupation }\end{array}$ & 1 & 206 & $40.8 \%$ & & $\begin{array}{c}\text { Luxury } \\
\text { consumption }\end{array}$ & $\begin{array}{c}\text { Rank } \\
\text { variable }\end{array}$ & & \\
\hline & $\begin{array}{l}\text { Engel's } \\
\text { coefficient }\end{array}$ & $\begin{array}{c}\text { Rank } \\
\text { variable }\end{array}$ & & & & & & & \\
\hline & $0-30 \%$ & 1 & 114 & $22.6 \%$ & & \multirow{3}{*}{$\begin{array}{c}\text { Never } \\
\text { Occasionally } \\
\text { A few times a } \\
\text { year }\end{array}$} & 1 & 223 & $44.2 \%$ \\
\hline & $30-60 \%$ & 2 & 244 & $48.3 \%$ & & & 2 & 164 & $32.5 \%$ \\
\hline & $>60 \%$ & 3 & 147 & $29.1 \%$ & & & 3 & 93 & $18.4 \%$ \\
\hline \multirow{19}{*}{$\begin{array}{l}\text { Shopping } \\
\text { behavior }\end{array}$} & $\begin{array}{c}\text { Frequency of } \\
\text { online } \\
\text { shopping }\end{array}$ & $\begin{array}{c}\text { Rank } \\
\text { variable }\end{array}$ & & & & Once a month & 4 & 20 & $4.0 \%$ \\
\hline & Never & 1 & 109 & $21.6 \%$ & & Constantly & 5 & \multirow[t]{3}{*}{5} & \multirow[t]{3}{*}{$1 \%$} \\
\hline & Occasionally & 2 & 185 & $36.6 \%$ & & Impulse & Rank & & \\
\hline & Always & 3 & 203 & $40.2 \%$ & & consumption & variable & & \\
\hline & ALL & 4 & 8 & $1.6 \%$ & & Never & 1 & 10 & $2.0 \%$ \\
\hline & $\begin{array}{l}\text { Amount of } \\
\text { money ratio } \\
\text { of online } \\
\text { shopping }\end{array}$ & $\begin{array}{c}\text { Rank } \\
\text { variable }\end{array}$ & & & & Rarely & 2 & 36 & $7.1 \%$ \\
\hline & $<10 \%$ & 1 & 139 & $27.5 \%$ & & Occasionally & 3 & 183 & $36.2 \%$ \\
\hline & $10-30 \%$ & 2 & 167 & $33.1 \%$ & & Constantly & 4 & 276 & $54.7 \%$ \\
\hline & $30-50 \%$ & 3 & 132 & $26.1 \%$ & & Excessive & Rank & & \\
\hline & $\begin{array}{c}50-70 \% \\
70-100 \%\end{array}$ & $\begin{array}{l}4 \\
5\end{array}$ & $\begin{array}{l}52 \\
15\end{array}$ & $\begin{array}{c}10.3 \% \\
3 \%\end{array}$ & & consumption & variable & 302 & $598 \%$ \\
\hline & $\begin{array}{l}\text { Goods of } \\
\text { online } \\
\text { shopping }\end{array}$ & $\begin{array}{c}\text { Categorical } \\
\text { variable }\end{array}$ & & & & Occasionally & 2 & 128 & $25.3 \%$ \\
\hline & $\begin{array}{l}\text { Commodity } \\
\text { (daily } \\
\text { necessities, } \\
\text { food) } \\
\text { Non- }\end{array}$ & 0 & 188 & $37.2 \%$ & & $\begin{array}{l}\text { Often, } \\
\text { interest-free } \\
\text { period } \\
\text { repayment }\end{array}$ & 3 & 67 & $13.3 \%$ \\
\hline & $\begin{array}{l}\text { Commodity } \\
\text { (books, } \\
\text { clothing, } \\
\text { electrical } \\
\text { appliances) }\end{array}$ & 1 & 317 & $62.8 \%$ & & $\begin{array}{l}\text { Often, with } \\
\text { interest } \\
\text { payments }\end{array}$ & 4 & 8 & $1.6 \%$ \\
\hline & $\begin{array}{l}\text { Goods of } \\
\text { offline } \\
\text { shopping }\end{array}$ & $\begin{array}{c}\text { Categorical } \\
\text { variable }\end{array}$ & & & & $\begin{array}{l}\text { Emerging } \\
\text { consumption }\end{array}$ & $\begin{array}{c}\text { Rank } \\
\text { variable }\end{array}$ & & \\
\hline & commodity & 0 & 224 & $44.4 \%$ & & & & & \\
\hline & $\begin{array}{l}\text { Non- } \\
\text { commodity }\end{array}$ & 1 & 281 & $55.6 \%$ & & Maladjustment & 1 & 144 & $28.5 \%$ \\
\hline & $\begin{array}{c}\text { Purpose of } \\
\text { offline } \\
\text { shopping }\end{array}$ & $\begin{array}{c}\text { Categorical } \\
\text { variable }\end{array}$ & & & & That's acceptable & 2 & 190 & $37.6 \%$ \\
\hline & $\begin{array}{l}\text { Shopping } \\
\text { and dining }\end{array}$ & 0 & 218 & $43.2 \%$ & & I'm interested & 3 & 135 & $26.7 \%$ \\
\hline & $\begin{array}{l}\text { Entertainment } \\
\text { and leisure }\end{array}$ & 1 & 287 & $56.8 \%$ & & $\begin{array}{l}\text { I'm very } \\
\text { interested }\end{array}$ & 4 & 36 & $7.1 \%$ \\
\hline
\end{tabular}

\subsubsection{Hypotheses}

Residents' shopping behaviors are complex, and the decisions affecting behaviors may be interrelated. Many scholars have conducted a lot of theoretical and empirical research. Early in 1997, Golledge et al. summarized the influencing factors of decision-making behaviors into individual biological attributes (such as gender, age, etc.), sociological attributes (such as occupation, social status, race, etc.), spatial attributes (such as location, distribution characteristics, etc.), and emotional attributes (such as beliefs, values, etc.) [39]. Ibrahim et al. also summarized the influencing factors of shopping behaviors into four types, namely, the consumer's personal attributes, store attributes, shopping context, and traffic situation [40]. Ma et al. and Fu et al. proposed that the influencing factors of 
consumer behaviors can be divided into consumer personal and family variables, shopping activities, spatial variables, and consumer cognition and preferences [41].

The main aim of this paper was to explore how the arrival of new consumption will affect residents' consumption attitudes and shopping behaviors in different kinds of communities. Based on this research aim, and with a supporting review of the literature, three factors affecting the residents' shopping behaviors were identified as relevant in this study: residents' characteristics, community properties, and consumption attitudes in the new consumption era. Figure 3 illustrates the hypothesized links between these variables. The three variables were all assumed to have direct effects on the shopping behaviors. The residents' characteristics were hypothesized to directly influence the property of community; that is, differences in residents' characteristics will lead to differences in their choice of community directly. Moreover, the residents' characteristics and community properties were all assumed to affect residents' consumption attitudes, which means that, through their direct impact on consumption attitude, these two variables may also indirectly affect shopping behavior.

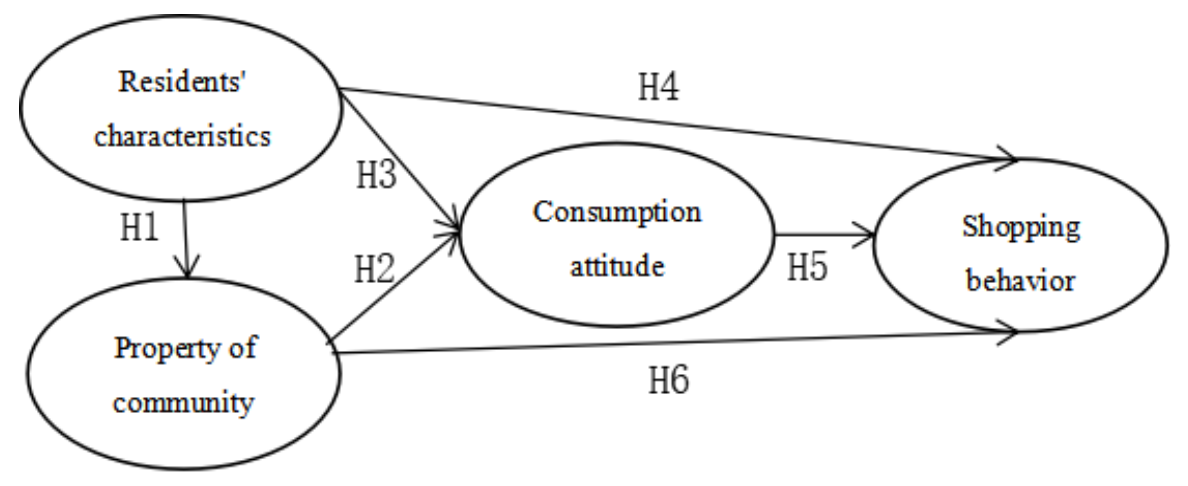

Figure 3. Theoretical framework and path hypothesis.

Hypotheses 1 (H1). Residents' characteristics have a significant effect on the community properties.

Hypotheses 2 (H2). Community properties have a significant effect on consumption attitudes.

Hypotheses 3 (H3). Residents' characteristics have a significant effect on consumption attitudes.

Hypotheses 4 (H4). Residents' characteristics have a significant effect on shopping behaviors.

Hypotheses 5 (H5). Consumption attitudes have a significant effect on shopping behaviors.

Hypotheses 6 (H6). Community properties have a significant effect on shopping behaviors.

\section{Characteristics of Shopping Behaviors of Residents}

\subsection{Characteristics of Online Shopping Behavior}

With the coming of the new consumption era, online shopping has become increasingly popular, and its advantages, such as convenience, speed, low price, and variety of types, have increasingly impacted traditional offline shopping. In terms of the frequency of online shopping, $40.44 \%$ of residents of Hohhot often shop online, and about $21.71 \%$ of residents have never shopped online. From the perspective of different communities (Figure 4), because the overall living standard of UV residents is relatively low, their acceptance level of online shopping is low. More than half of the residents in UVs never buy online, and the spending of online shopping accounts for a small percentage of the total spending, which is less than $10 \%$. Residents in HCs also show a relatively low online shopping frequency and spending due to their older age. A high frequency of online shopping is found in the MCs, MGCs, and HGCs, with over $80 \%$ of the residents having an online shopping experience. MGCs are far from city centers, but their proportion of online shopping spending is not much different from that of MCs. This shows that location of community has little influence 
on whether residents' go online or offline shopping. The proportion of online shopping spending in the HGCs is highest, ranging from $30 \%$ to $70 \%$.

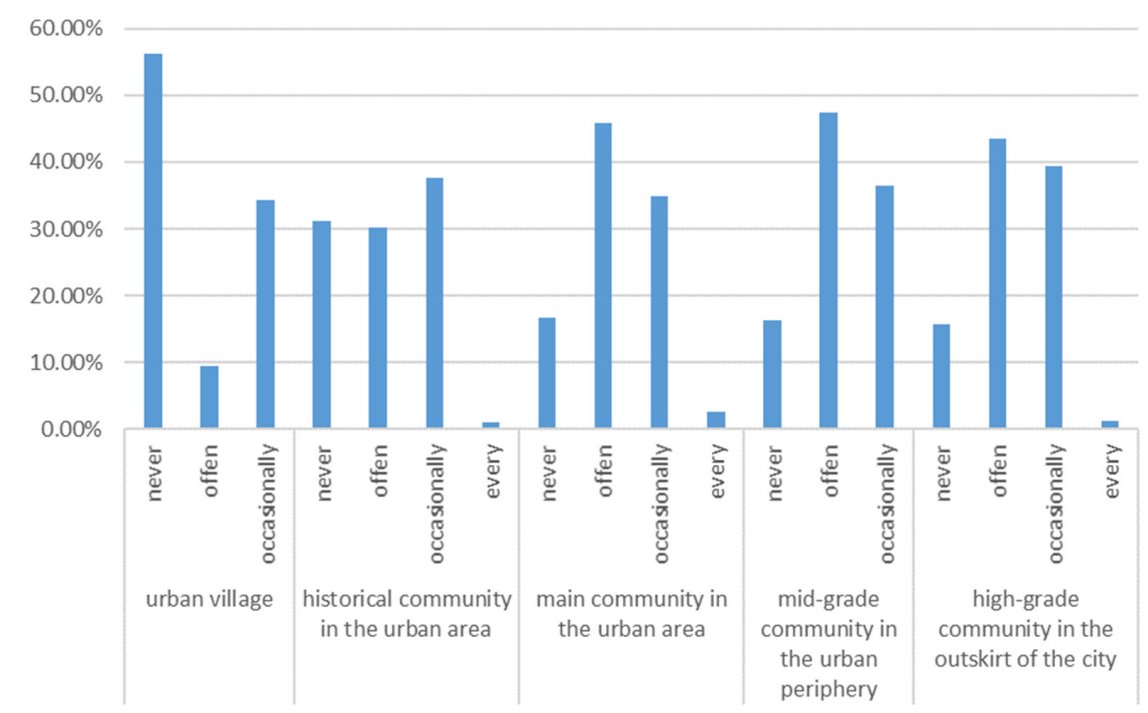

(a)

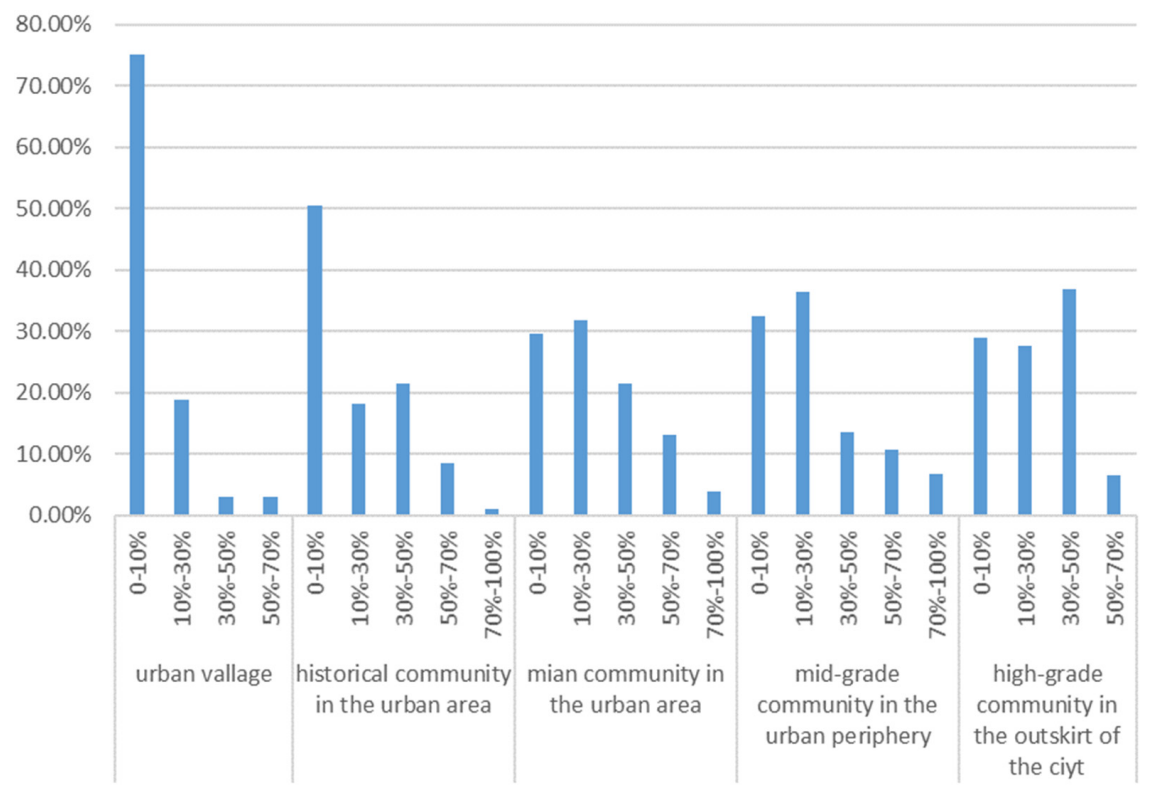

(b)

Figure 4. Frequency and online shopping spending for different types of community: (a) Frequency of online shopping. (b) Online shopping spending as a proportion of total spending.

From the perspective of the types of goods purchased by residents online, residents of all types of community have a higher ratio of online shopping in clothing, shoes and hats, and household products. Residents in UVs mostly choose offline shopping, and their online shopping is mainly for household products. Residents in MCs have a slightly higher proportion of online shopping for books, while residents in HCs have the largest proportion on clothing, shoes, and hats. Residents in MGCs and HGCs have the largest proportion of online shopping for beauty care and books, indicating that these types of community are highly dependent on online shopping, and that e-commerce has penetrated their daily shopping (Figure 5). 


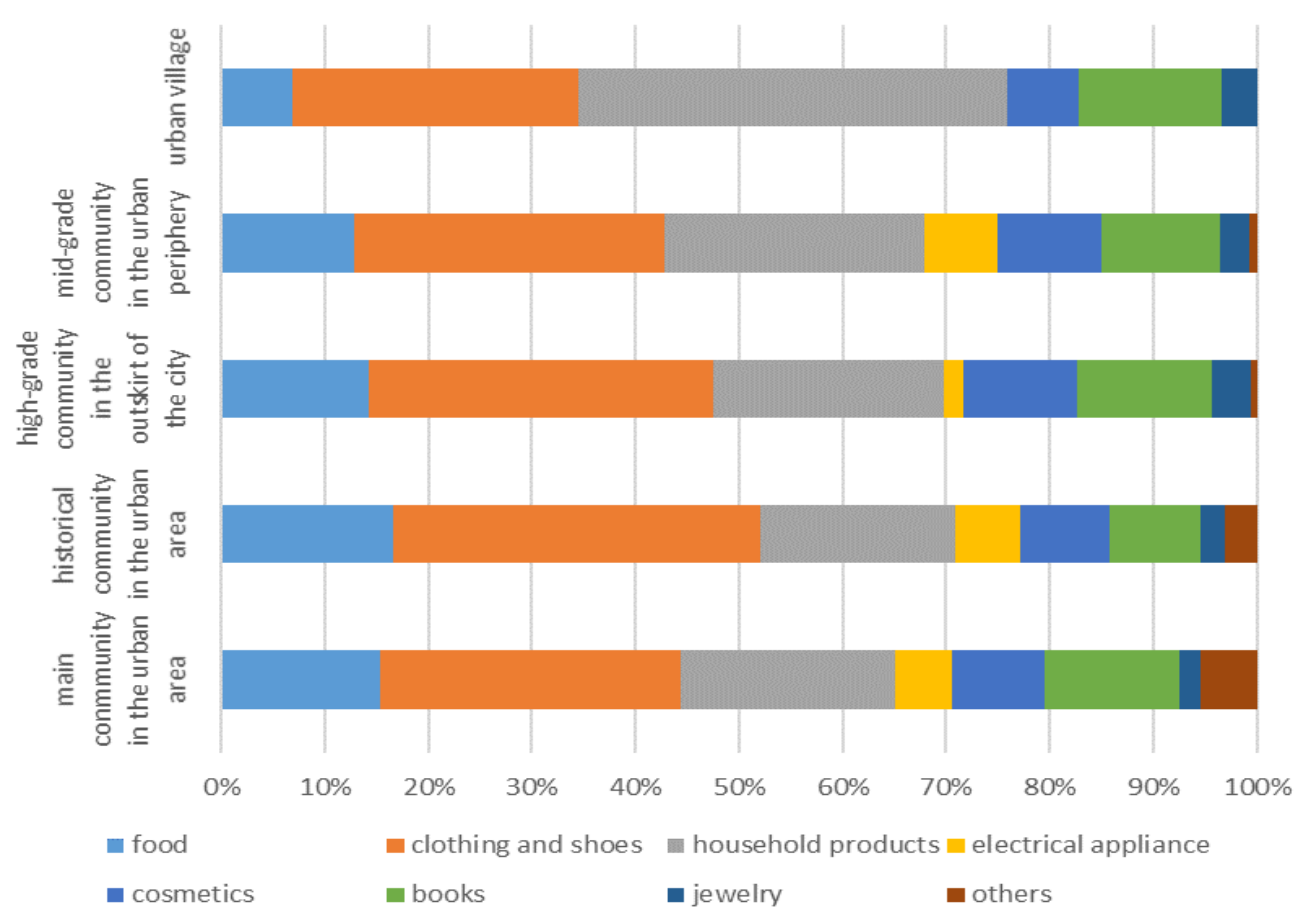

Figure 5. Types of goods purchased online.

\subsection{Characteristics of Offline Shopping Behavior}

Compared with online shopping, offline shopping has the advantages of comprehensive service. In Hohhot, $82.3 \%$ of residents shop for various things offline, mainly including purchasing, dining, leisure, and entertainment.

From the perspective of community type, the living standard of residents in UVs is lower, and their income is used, for the most part, for day-to-day living. Purchasing mainly occurs in vegetable markets and supermarkets near their communities. Therefore, the types of goods purchased offline are household goods, food, and health care, followed by clothing, shoes, and hats; the proportion of these types of goods is much higher than that of the others, more than $80 \%$. Residents in HCs have less consumption of basic daily necessities than residents in UVs, but among all types of community, the proportion of basic daily necessities consumption still ranks second, accounting for more than $70 \%$. In the most important types of community, MCs and MGCs, the main types of goods consumption consists of basic daily necessities, such as food and health care, clothing, shoes and hats and daily necessities. The proportion of books purchased is significantly higher than that of UVs and HCs. The residents in HGCs have higher incomes and superior economic conditions, and their consumption needs for leisure and entertainment are greater. Therefore, the basic daily necessities consumption of residents in HGCs, especially of household products, is the lowest of all types of community, regarding offline consumption; however, the purchase of jewelry in HGCs accounts for the highest proportion of consumption of all types of community (Figure 6). 


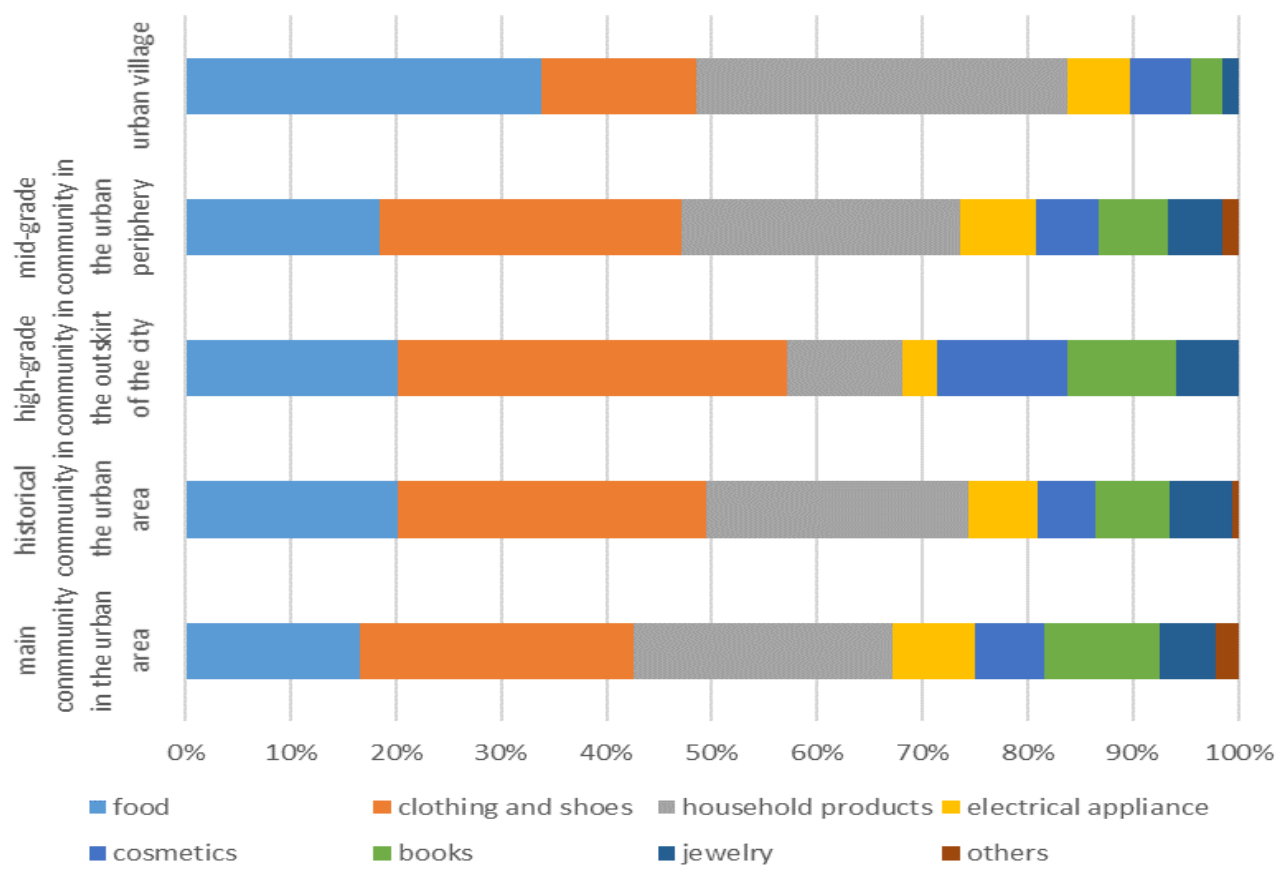

Figure 6. Types of goods purchased offline.

This study analyzed the flow and direction of the offline shopping travel of residents with respect to community type (Figure 7).

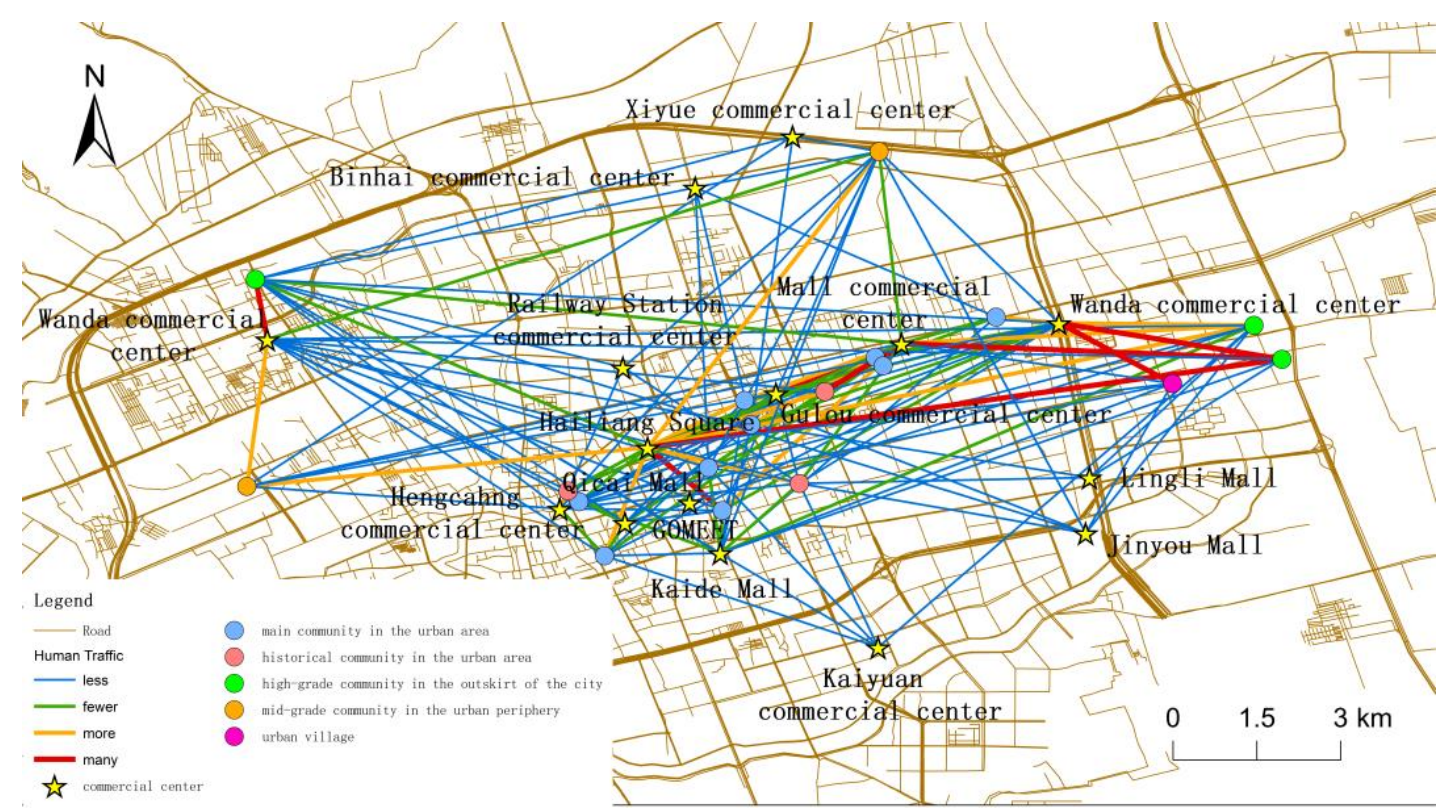

Figure 7. Offline shopping travel flow of residents with regard to community type.

MCs are mainly located on both sides of the main arterial roads in the city center, with convenient transportation. Residents in MCs show strong diversity in their choice of commercial center for offline shopping, paying more attention to a good shopping experience and maximizing the available categories of commodity. Therefore, such shoppers are attracted to larger and more comprehensive commercial centers, including Hailiang Commercial Center and Wanda Commercial Center, as well as auxiliary commercial centers around their communities. The residents in HCs always only have one choice of commercial center-one that is close to their community. In the field survey, most residents in HCs 
purchased daily necessities and food in the surrounding vegetable markets or supermarkets only, occasionally going to a commercial center for dining and entertainment. MGCs are located on the outskirts of the city. The residents of these communities aim for the more comprehensive commercial centers in the surrounding areas. However, the city's core commercial centers, such as Hailiang Commercial Center and Moore Commercial Center, also prove attractive to the residents. Residents in HGCs have a wide range of choices of offline shopping travel to commercial centers, and the proportion of high-end commercial center travel flow is the highest in HGCs. Residents' shopping behaviors in UVs mostly comprised of buying vegetables in the surrounding vegetable markets and supermarkets, occasionally going to commercial centers nearby for dining and entertainment.

\section{The Influence of Various Factors on Residents' Shopping Behaviors}

Based on the proposed theoretical framework and path hypothesis proposed in Section 3.3.3, an initial ideal model was constructed (Figure 8). From the result of the initial model, except for when the ratio of the chi-square value to the degrees of freedom is $5.1>3$, the other indexes basically met the recommended value standards. However, the model needs refinement. First, three untested variables were deleted: gender and HGC $(p>0.05)$, as well as the influencing path of community properties on shopping behavior $(p>0.05)$. The original model was then revised repeatedly with reference to the revised index to improve the model's overall accuracy: HC and HGC, and HGC and MC are related; this indicates that these two pairs of observed variables have a higher correlation. We can delete one variable from each of the two pairs of variables with the high correlation. Deleting HC and HGC reduces the chi-square value more $(>80)$ and improves the model. The model was then built again, and the fitting indexes were evaluated (Figure 9, Table 3). After the model was revised, the ratio of the chi-square value to the degrees of freedom was 2.173, and the normative fitting index (NFI), incremental fitting index (IFI), Tucker-Lewis index (TLI), and comparative fitting index (CFI) were all over 0.90; the root mean square RMSEA of the approximate error was 0.049 , which is less than 0.05 , meaning the model fitted well.

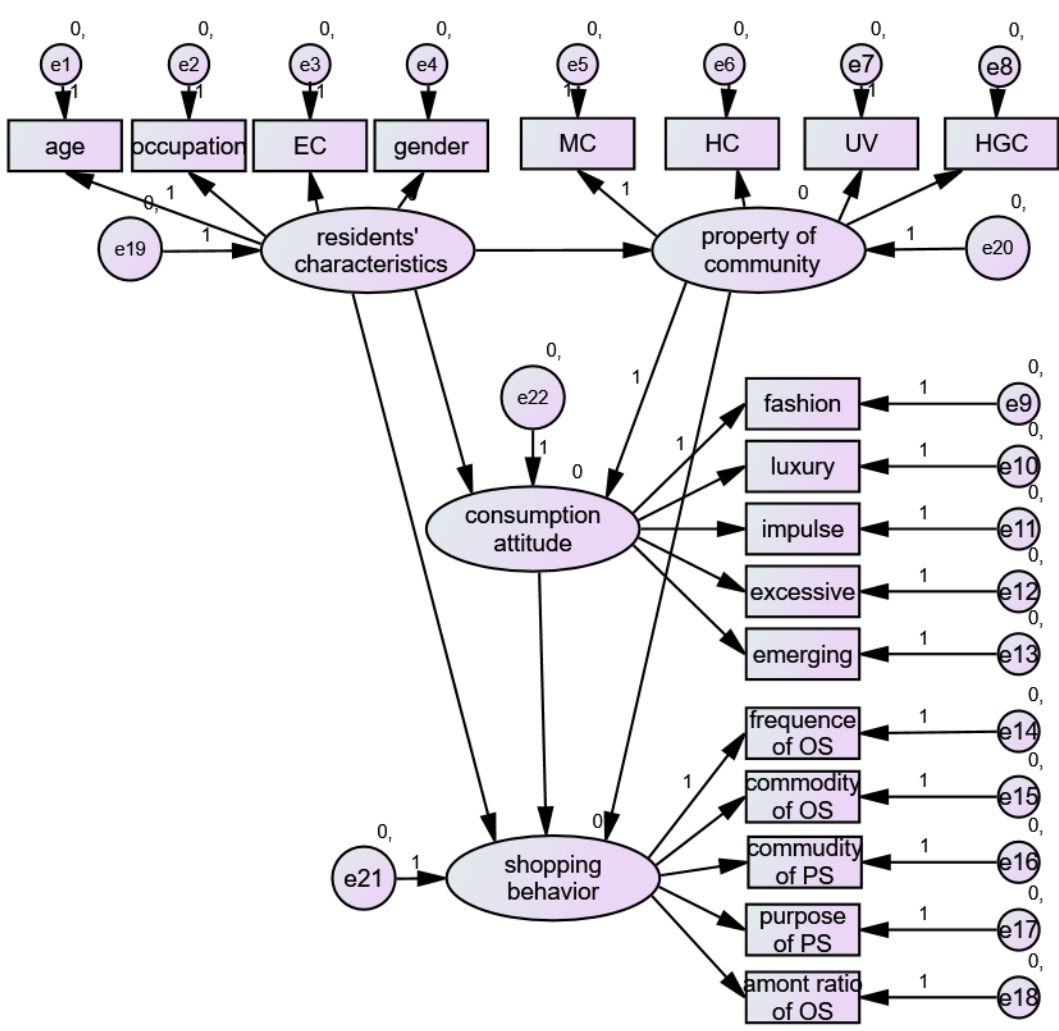

Figure 8. Diagrammatic sketch of conceptual structural equation model. 


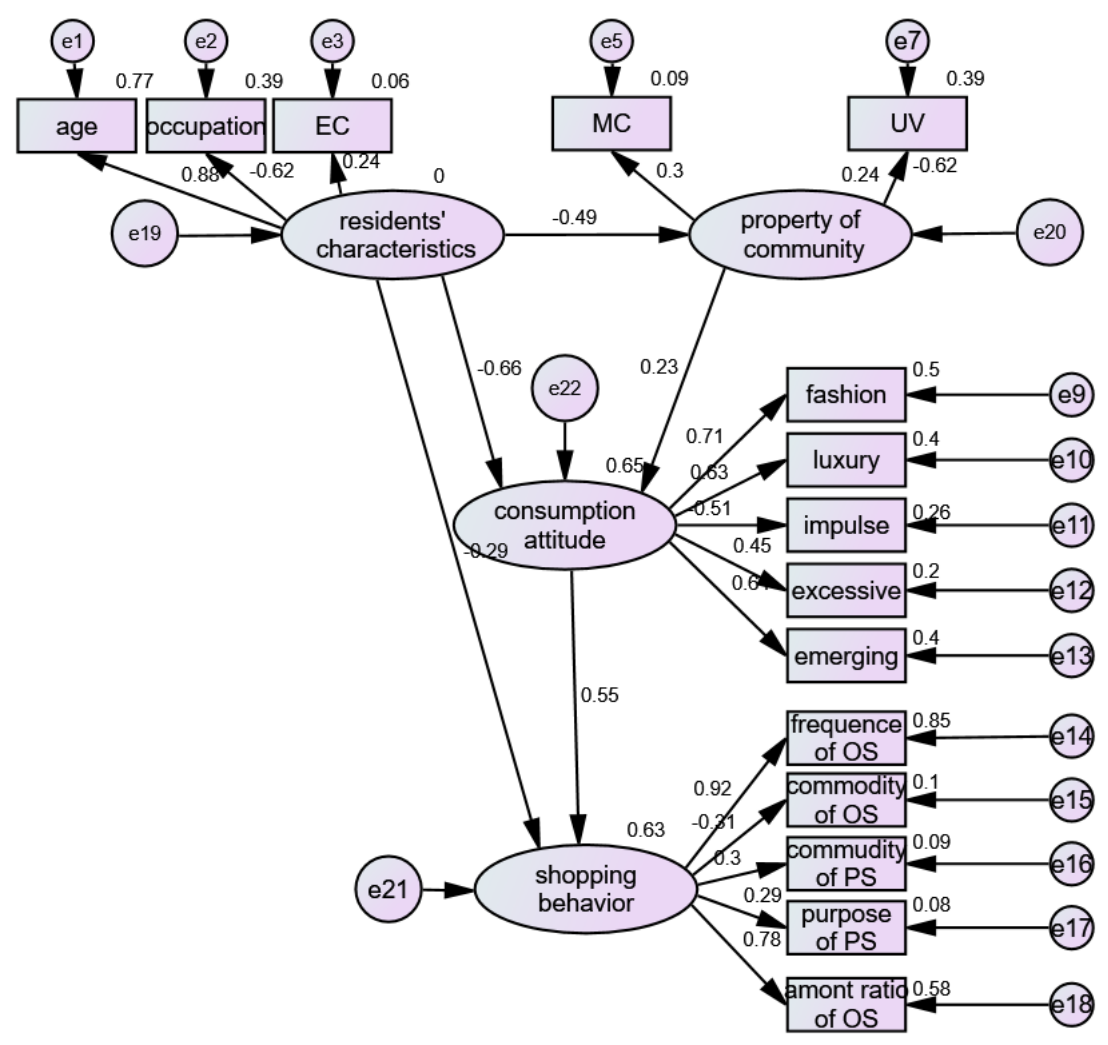

Figure 9. The modified structural equation model after correction.

Table 3. Comprehensive list of fit indexes.

\begin{tabular}{cccc}
\hline Fitness Index & $\begin{array}{c}\text { Criteria for } \\
\text { Determination }\end{array}$ & $\begin{array}{c}\text { Corrected Fitting } \\
\text { Value }\end{array}$ & Fitting Evaluation \\
\hline CMIN/DF & $<3$ & 2.173 & Ideal \\
NFI & $>0.90$ & 0.902 & Ideal \\
IFI & $>0.90$ & 0.944 & Ideal \\
TLI & $>0.90$ & 0.931 & Ideal \\
CFI & $>0.90$ & 0.944 & Ideal \\
RMSEA & $<0.05$ & 0.049 & Ideal \\
\hline
\end{tabular}

According to the results, path verification of the SEM (Table 4) and the chain effects between latent variables (Table 5) is obtained. Comparing the path of the revised SEM with the research hypothesis shows that Hypothesis H6 does not exist, and that the other five hypotheses all pass the fit test:

H1 The effect of residents' characteristics on community properties: the direct impact of residents' socio-economic characteristics on community properties is 0.492 , indicating that different socio-economic characteristics will affect the choice of community type. For example, residents with a higher Engel coefficient live more in UVs.

H2 The effect of the community property on residents' consumption attitude: the direct influence of community property on consumption attitude is 0.231 , and the influence of the community property on shopping behaviors through consumption attitude is $\mathrm{H} 2 \times \mathrm{H} 5=0.127$. For example, most residents living in UVs do not have stable working conditions and have low incomes. Therefore, their acceptance of new consumption trends, such as emerging consumption and fashionable consumption is low. Such consumption attitudes affect their shopping behaviors.

H3 The effect of the residents' characteristics on consumption attitude: the direct effect of residents' characteristics on consumption attitude is 0.662 , and the indirect effect 
is $\mathrm{H} 2 \times \mathrm{H} 1=0.114$. This shows that residents' characteristics can directly affect emerging consumption attitudes, and indirectly lead to differences in residents' attitudes towards emerging consumption through different types of community, but the indirect effect is small. Variables such as age, occupation, and the Engel coefficient all pass the significance test, which shows that these variables can explain the residents' characteristics well and influence consumer's attitudes regarding consumption. The age, occupation, and Engel coefficient of the residents' characteristics all pass the significance test, indicating that these variables explain well the different attributes of residents, affecting the residents' attitudes to consumption to varying degrees. Among the residents' variables, the regression coefficients of the standard path of the age and the occupation of residents are large, indicating that these two variables have a considerable impact on residents' consumption attitudes. The younger the residents and the more stable the work of residents, the higher degree of acceptance of the fashion consumption, luxury consumption, excessive consumption, and emerging consumption in the new consumption era. Residents with a high Engel coefficient have limited channels for accepting new things, which directly affects their consumption attitudes.

H4 The effect of the residents' characteristics on their shopping behaviors: the direct effect of residents' characteristics on their shopping behavior is 0.287 , and the indirect effect generated by consumption attitudes on shopping behavior is 0.366 . This shows that residents' characteristics not only directly affect their shopping behavior, but also that they indirectly affect their shopping behavior through consumer attitudes. For example, residents who are younger and have a stable professional status are more likely to receive new things, involving luxury consumption, emerging consumption, and advanced consumption; they often have a higher frequency for online shopping.

H5 The effect of consumption attitudes on residents' shopping behaviors: Residents' attitudes directly affect their shopping behaviors, with a direct effect of 0.551 . The model shows that residents' behaviors are most affected by consumption attitudes in the new consumption era. In addition to the direct effect, the two latent variables of residents' characteristics and community properties have the indirect influence on residents' shopping behaviors through consumption attitude. The observed variables reflecting consumption attitude, emerging consumption, excessive consumption, impulse consumption, luxury consumption, and fashion consumption all pass the test. This indicates that these variables greatly impact residents' shopping behaviors. Specifically, and with regard to fashion consumption and emerging consumption, the frequency and the amount of money of the residents who buy products through the internet are increasing. Residents who are influenced by impulse consumption are less inclined to buy luxury goods. 
Table 4. Path verification of structural equation model after correction.

\begin{tabular}{|c|c|c|c|c|c|c|}
\hline & Path & & Estimate & S.E. & C.R. & $p$ \\
\hline $\begin{array}{l}\text { Property of } \\
\text { community }\end{array}$ & $<-$ & $\begin{array}{c}\text { Residents' } \\
\text { characteristics }\end{array}$ & -1.067 & 0.019 & -1.456 & $* * *$ \\
\hline Consumption attitude & $<-$ & $\begin{array}{l}\text { Property of } \\
\text { community }\end{array}$ & 1.000 & - & - & - \\
\hline Consumption attitude & $<-$ & $\begin{array}{c}\text { Residents' } \\
\text { characteristics }\end{array}$ & -1.391 & 0.043 & -1.187 & $* * *$ \\
\hline Shopping behavior & $<-$ & Consumption attitude & 0.625 & 0.107 & 5.850 & $* * *$ \\
\hline Shopping behavior & $<-$ & $\begin{array}{c}\text { Residents' } \\
\text { characteristics }\end{array}$ & -1.191 & 0.060 & -1.164 & 0.002 \\
\hline Fashion & $<-$ & Consumption attitude & 1.000 & - & - & - \\
\hline Luxury & $<-$ & Consumption attitude & 0.898 & 0.073 & 12.334 & $* * *$ \\
\hline Impulse & $<-$ & Consumption attitude & -1.563 & 0.056 & -10.149 & $* * *$ \\
\hline Excessive & $<-$ & Consumption attitude & 0.536 & 0.060 & 8.890 & $* * *$ \\
\hline Frequency of OS & $<-$ & Shopping behavior & 1.000 & - & - & - \\
\hline Commodity of OS & $<-$ & Shopping behavior & -1.204 & 0.030 & -1.704 & $* * *$ \\
\hline Commodity of PS & $<-$ & Shopping behavior & 0.204 & 0.031 & 6.521 & $* * *$ \\
\hline Emerging & $<-$ & Consumption attitude & 0.893 & 0.072 & 12.428 & $* * *$ \\
\hline Occupation & $<-$ & $\begin{array}{c}\text { Residents' } \\
\text { characteristics }\end{array}$ & -1.282 & 0.023 & -12.470 & $* * *$ \\
\hline Purpose of PS & $<-$ & Shopping behavior & 0.194 & 0.031 & 6.190 & $* * *$ \\
\hline $\mathrm{EC}$ & $<-$ & $\begin{array}{c}\text { Residents' } \\
\text { characteristics }\end{array}$ & 0.158 & 0.032 & 5.011 & $* * *$ \\
\hline $\mathrm{MC}$ & $<-$ & $\begin{array}{l}\text { Property of } \\
\text { community }\end{array}$ & 1.000 & - & - & - \\
\hline Amount ratio of OS & $<-$ & Shopping behavior & 1.159 & 0.063 & 18.421 & $* * *$ \\
\hline UV & $<-$ & $\begin{array}{l}\text { Property of } \\
\text { community }\end{array}$ & -1.016 & 0.291 & -1.488 & $* * *$ \\
\hline Age & $<-$ & $\begin{array}{c}\text { Residents' } \\
\text { characteristics }\end{array}$ & 1.000 & - & - & - \\
\hline
\end{tabular}

Note: ${ }^{* * *}$ significant at $1 \%$ significance level.

Table 5. Diagrammatic sketch of standardized chain effects between latent variables.

\begin{tabular}{ccc}
\hline Path (Total Effect) & Direct Path (Direct Effect) & $\begin{array}{c}\text { Indirect Path (Indirect } \\
\text { Effect) }\end{array}$ \\
\hline $\begin{array}{c}\text { Residents' characteristics } \rightarrow \\
\text { Property of community }(0.492)\end{array}$ & $\begin{array}{c}\text { Residents' characteristics } \rightarrow \\
\text { Property of community }(0.492)\end{array}$ & \\
Residents' characteristics $\rightarrow$ & Residents' characteristics $\rightarrow$ & Residents' characteristics $\rightarrow$ \\
Consumption attitude $(0.778)$ & Consumption attitude $(0.665)$ & Property of community $\rightarrow$ \\
Residents' characteristics $\rightarrow$ & Residents' characteristics $\rightarrow$ & Residents' characteristics $\rightarrow$ \\
Shopping behavior $(0.715)$ & Shopping behavior $(0.287)$ & Consumption attitude $\rightarrow$ \\
Property of community $\rightarrow$ & Property of community $\rightarrow$ & Shopping behavior $(0.429)$ \\
Consumption attitude $(0.231)$ & Consumption attitude $(0.231)$ & Property of community $\rightarrow$ \\
Property of community $\rightarrow$ & & Consumption attitude $\rightarrow$ \\
Shopping behavior $(0.127)$ & & Shopping behavior $(0.127)$ \\
Consumption attitude $\rightarrow$ & Consumption attitude $\rightarrow$ & \\
Shopping behavior $(0.551)$ & Shopping behavior $(0.551)$ & \\
\hline
\end{tabular}

\section{Conclusions and Discussion}

In the new consumption era, mass consumption attitudes and behaviors have undergone profound changes. Using Hohhot as a case, this study explored the characteristics of shopping behaviors, and employed a structural equations model to investigate the associations among residents' characteristics, community properties, and consumption attitudes in the new consumption era. Its contribution to the literature is twofold: First, 
the paper theorizes different segments of consumers based on geography, such as urban communities of MCs, HCs, HGCs, MGCs, and UVs in the city. This is not very common in consumer behavior studies, most of which focus on e-shopping behavior using prior theories, and is therefore one of the strong points of the paper in our view. Second, the paper reveals how the new consumption era affects residents' consumption attitudes and shopping behaviors. Although a lot of existing studies explore the characteristics and relationship between online shopping and offline shopping in the internet era, the role of the more complex new consumption attitudes, such as emerging consumption, excessive consumption, impulse consumption, luxury consumption, and fashion consumption are not fully discussed; as well as the interrelationship of the various variables of the shopping behaviors, including the new consumption attitudes that are rarely taken into account. As such, this paper is helpful in gaining a deeper understanding of the characteristics and mechanism of shopping behaviors in the new consumption era, and provides the possibility to establish predictive models to simulate the shopping behaviors in different communities in the city. The main research conclusions are as follows: (1) Considering all the kinds of attributes and spatial locations of the communities, communities in Hohhot can be divided into five types: main community in the urban area, historical community in the urban area, high-grade community in the outskirts of the city, mid-grade community in the urban periphery, and urban village. (2) Residents of different types of communities show significant differences in their online and offline shopping behavioral characteristics. For example, residents in HGCs have the lowest proportion of basic daily necessities, especially household daily necessities, while the proportion of jewelry in offline shopping is highest in HGCs out of all the types of community. Although the offline shopping of residents in MCs and HCs is mainly comprise of daily necessities, residents in MCs shop mainly for books online, and residents in HCs mainly shop for clothing, shoes, and hats online. (3) Residents' shopping behaviors present multiple and differentiated paths, and a resident's socio-economic characteristics, such as age, occupation, and Engel coefficient, directly affects their shopping behaviors. Typical consumption attitudes of the new era, such as luxury and emerging consumption attitudes, have the most significant and direct influence on shopping behaviors. Specifically, residents' choice of community and where to live (community property) are directly affected by their characteristics, and although different types of community (community property) cannot directly affect residents' shopping behaviors, they affect them indirectly by influencing consumption attitudes.

In terms of managerial contributions, this paper can enrich the research results of shopping behaviors in China, especially in the western cities, which can provide an important reference to the government for formulating and adjusting commercial network plans from a fair perspective. Firstly, the study has found that the property of the community will affect the shopping behaviors by influencing residents' consumption attitudes. Therefore, the UAs are relatively remote in the city, as most residents living in UVs do not have stable working conditions and have low incomes. As such, in the urban-rural fringe area, lowend, and comprehensive commercial centers should be factored in, and the bus and subway accessibility of these commercial centers should be improved to meet their basic shopping needs. Secondly, the study has found that the behavior of residents is most affected by new consumption attitudes in the new era, such as emerging consumption, excessive consumption, impulse consumption, etc. Therefore, the operators of commercial centers and e-tailers can reasonably improve the types of commodities, consumption environment, or service levels according to residents' emerging consumption attitudes. For example, as residents' acceptance of fashion and emerging consumption increases in the new consumption era, more people prefer online consumption and diverse consumer experiences. In this way, the operators of commercial centers need to increase their product categories and enrich their experience, as well as consider combining offline sales with online sales. This paper also has some shortcomings: the on-site survey cases of communities and the respondents are all limited, so the paper may have a certain representative bias. With the increasing complexity of online shopping models in recent years, emerging models, such as those 
involving online consumption and offline experience, and involving day-to-day fruit and vegetable products with online and offline integration, are not considered in this paper. In addition, this paper is based on a survey of different community types without considering the relative location, scale, environment, and other attributes of urban commercial centers. In the future, it will be necessary to conduct in-depth research involving these attributes.

Author Contributions: This study was conducted under cooperation between F.N. and F.W. Writing original draft preparation, F.W.; Methodology, F.N.; visualization, F.N.; supervision, F.W. Both authors have read and agreed to the published version of the manuscript.

Funding: This research was funded by the National Natural Science Foundation of China, grant number 41801149 and 42071153; Young Talents of Science and Technology in Universities of Inner Mongolia, grant number NJTY-20-B09.

Data Availability Statement: Publicly available datasets were analyzed in this study. A part of the data can be found here: [https:// huhehaote.anjuke.com/community/?from=esf_list], accessed on 1 September 2019.

Conflicts of Interest: The authors declare no conflict of interest.

\section{References}

1. Grand View Research. Online Grocery Market Size, Share Trends Analysis Report by Product Type (Fresh Produce, Breakfast Dairy, Snacks Beverages, Staples Cooking Essentials), by Region, and Segment Forecasts, 2020-2027. Technical Report. Grand View Research Inc. 2020. Available online: https:/ /www.grandviewresearch.com/industry-analysis/online-grocery-market (accessed on 2 February 2021).

2. You, H.; Yang, J.; Xue, B.; Xiao, X.; Xia, J.; Jin, C.; Li, X. Spatial Evolution of Population Change in Northeast China During 1992-2018. Sci. Total Environ. 2021, 776, 146023. [CrossRef]

3. Lim, W.M.; Gupta, S.; Aggarwal, A.; Paul, J.; Sadhna, P. How do digital natives perceive and react toward online advertising? Implications for SMEs. J. Strateg. Mark. 2021, in press.

4. Ozuduru, B.H.; Varol, C.; Yalciner Ercoskun, O. Do shopping centers abate the resilience of shopping streets? The co-existence of both shopping venues in Ankara, Turkey. Cities 2014, 36, 145-157. [CrossRef]

5. Wang, F.; Niu, F.; Wang, Z. Commercial spatial structure optimization based on trade area analysis from a micro-scale perspective in Beijing. Geogr. Res. 2017, 9, 1697-1708. (In Chinese)

6. Geiger, S. Exploring night-time grocery shopping behavior. J. Retail. Consum. Serv. 2007, 14, 24-34. [CrossRef]

7. Fu, C.; Zhou, S.; Yan, X.; Liu, L.; Chen, W. Spatio-temporal characteristics and influencing factors of consumer behavior in retailing centers: A case study of Guangzhou in Guangdong. Acta Geogr. Sin. 2017, 72, 603-617.

8. Badawi, S.; Farag, A.A. Young Saudi Women's travel behavior change over 2015/2020. J. Transp. Health 2021, 21, 101080. [CrossRef]

9. Eger, L.; Komárková, L.; Egerová, D.; Mičík, M. The effect of COVID-19 on consumer shopping behaviour: Generational cohort perspective. J. Retal. Consum. Serv. 2021, 61, 102542. [CrossRef]

10. Wang, D.; Zhu, W. Commercial Pedestrian Street-Research on Spatial Structure and Consumer Behavior; Tongji University Press: Shanghai, China, 2012. (In Chinese)

11. Jaller, M.; Pahwa, A. Evaluating the environmental impacts of online shopping: A behavioral and transportation approach. Transport. Res. Part D Transp. Environ. 2020, 80, 102223. [CrossRef]

12. Zeng, G.; Go, F.; Vries, H. Paradox of authenticity versus standardization: Expansion strategies of restaurant groups in China. Int. J. Hosp. Manag. 2012, 31, 1090-1100. [CrossRef]

13. Miltiadis, D.L.; Vijay, R.; Ernesto, D. Big data and data analytics research: Frommetaphors to value space for collective wisdom in human decision making and smartmachines. Int. J. Semant. Web Inf. Syst. 2017, 13, 1-10.

14. Shen, C.; Chen, M.; Wang, C.C. Analyzing the trend of O2O commerce by bilingual text mining on social media. Comput. Hum. Behav. 2019, 101, 474-483. [CrossRef]

15. Ingham, J.; Cadieux, J.; Mekki Berrada, A. E-Shopping acceptance: A qualitative and meta-analytic review. Inf. Manag. 2015, 52, 44-60. [CrossRef]

16. Zhen, F.; Cao, X.; Mokhtarian, P.L.; Xi, G. Associations between online purchasing and store purchasing for four types of products in Nanjing, China. Transp. Res. Rec. 2016, 2566, 93-101. [CrossRef]

17. Zhang, D.; Zhu, P.; Ye, Y. The effects of E-commerce on the demand for commercial real estate. Cities 2016, 51, 106-120. [CrossRef]

18. Shi, K.; Yang, Y.; Shao, R. Spatial Pattern of Urban Resident's C2C Online Consumption in China: Feasibility of Innovation Diffusion Hypothesis and Efficiency Hypothesis. Sci. Geogr. Sin. 2019, 39, 107-115. (In Chinese)

19. Xi, G.; Zhen, F.; Cao, X.; Xu, F. The interaction between e-shopping and store shopping: Empirical evidence from Nanjing, China. Transp. Lett. 2020, 12, 157-165. [CrossRef] 
20. Zhang, Y.; Zhen, F. The Interaction Mode between Online Shopping and Store Shopping of Urban Resident and Spatial Differentiation-A Case Study of Nanjing. Econ. Geogr. 2017, 37, 15-22. (In Chinese)

21. Shi, K.; De Vos, J.; Yang, Y.; Witlox, F. Does e-shopping replace shopping trips? Empirical evidence from Chengdu, China. Transp. Res. Part A Policy Pract. 2019, 122, 21-33. [CrossRef]

22. Eveline, S.; Leeuwen, V.; Rietveld, P. Spatial consumer behavior in small and medium sized towns. Reg. Stud. 2010, 27, 1109-1119.

23. Zhang, Y.; Zhen, F. The influence of built environment on the choice of residents' shopping modes: A case study of Nanjing. Geogr. Res. 2019, 38, 313-325. (In Chinese)

24. Lim, W.M. Antecedents and consequences of e-shopping: An integrated model. Internet Res. 2015, 25, 184-217. [CrossRef]

25. Wang, F.; Gao, X. Structure of commercial space and its coupling relationship with population distribution in Beijing. City Plan. Rev. 2015, 39, 23-29. (In Chinese)

26. Zhang, X.; Chai, Y. Influencing factors of residents' commuting behavior in Xining:A SEM analysis using activity-travel diary survey data. Geogr. Res. 2018, 37, 2331-2343. (In Chinese)

27. Wang, F.; Gao, X.; Xu, Z. Identification and classification of urban commercial districts at block scale. Geogr. Res. 2015, 34, 1125-1134. (In Chinese)

28. Wang, F.; Niu, F. Urban Commercial Spatial Structure Optimization in the Metropolitan Area of Beijing: A Microscopic Perspective. Sustainability 2019, 11, 1103. [CrossRef]

29. Song, Z.; Xiao, T. Dose Spatial Distance Factor Still Matter in Online Shopping Behavior: A Study of Under graduates' Online Shopping in Guangzhou. Econ. Geogr. 2020, 40, 18-26. (In Chinese)

30. Lin, Y.; Wang, M.; Ma, T. The impact of online shopping on in-store shopping: An investigation of Nanfang Commercial Center in Shanghai. Word Reg. Stud. 2020, 29, 568-578. (In Chinese)

31. Shen, Y.; Ta, N.; Chai, Y. The Internet and the space-time flexibility of daily activities: A case study of Beijing, China. Cities 2020 97, 102493. [CrossRef]

32. Xi, G.; Cao, X.; Zhen, F. How does same-day-delivery online shopping reshape social interactions among neighbors in Nanjing? Citis 2021, 114, 130219.

33. Bollen, K.A. Structural Equations with Latent Variables; Wiley: New York, NY, USA, 1989.

34. Golob, T.F. Review structural equation modeling for travel behavior research. Transp. Res. Part B Methodol. 2003, 37, 1-5. [CrossRef]

35. Alonso, W. Location and Land Use: Toward a General Theory of Land Rent; Harvard University Press: Boston, MA, USA, 1964.

36. Ta, N.; Chai, Y.; Zhang, Y.; Sun, D. Understanding job-housing relationship and commuting pattern in Chinese cities: Past, present and future. Transp. Res. Part D Transp. Environ. 2017, 52, 562-573. [CrossRef]

37. Zhao, P.; Lv, B.; De, R.G. Impact of the jobs-housing balance on urban commuting in Beijing in the transformation era. J. Transp. Geogr. 2011, 19, 59-69. [CrossRef]

38. Lee, R.J.; Sener, I.N.; Mokhtarian, P.L.; Handy, S.L. Relationships between the online and in-store shopping frequency of Davis, California residents. Transp. Res. Part A Policy Pract. 2017, 100, 40-52. [CrossRef]

39. Golledge, R.G.; Stimson, R.J. Spatial Behavior: A Geographic Perspective; Guilford Press: New York, NY, USA, 1997.

40. Ibrahim, M.F.; McGoldrick, P.J. Shopping Choices with Public Transport Options: An Agenda for the 21st Century; Ashgate Publishing Company: Farnham, UK, 2003.

41. Ma, J.; Chai, Y. Spatio-temporal choice of individuals' shopping behavior and their differences between weekday and weekend. Sci. Geogr. Sin. 2011, 31, 29-35. (In Chinese) 